Derleme Makale • Review Article

\title{
Toplumsallığın Kurucu Aktörü Olarak Teknoloji: Eleştirel Bir Değerlendirme
}

\author{
Technology as Founding Actor of the Social: A Critical Review
}

Emin Baki ADAŞ**

0000-0002-9360-5804

\author{
Borabay ERBAY*
}

0000-0002-5744-1638

\section{MAKALE BILGİSI}

\section{Başvuru: 28.08.2021}

Düzeltme Talebi: 13.09 .2021

Son Düzeltme: 25.09.2021

Kabul: 07.12.2021

Online Yayım: 15.12 .2021

\section{Anahtar Kelimeler:}

Teknoloji

Sosyal Teori

Toplum

Aktör-Ağ Teorisi

Sosyoloji

\section{ARTICLE INFO}

Submitted: 28.08 .2021

Revision Requested: 13.09.2021

Final Revision Received: 25.09.2021

Accepted: 07.12.2021

Published Online: 15.12.2021

\section{Keywords:}

Technology

Social Theory

Society

Actor-Network Theory

Sociology
ÖZ

Teknoloji, en ilkel aletlerden karmaşık dijital teknolojilere kadar insanlık tarihinin merkezi bir bileşeni olmasına rağmen, sosyolojide çoğunlukla tali bir yerden ele alınmaktadır. Klasik sosyolojiden yakın geçmișe dek ana akım sosyolojinin teknoloji ile kurduğu ilișki çoğunlukla teknolojinin bir insan ürünü olarak ele alınması ve toplumsallığın üretiminde ve toplumsal yapının istikrar kazanmasında bir aktör olarak değil, insanın insan ile ilişkisinde bir araç olarak ele alınması şeklinde olmuştur. Teknolojinin toplumsal bir aktör olabileceği fikri çoğunlukla radikal bir düşünce olarak sosyolojinin kıyısında kalmıștır. Ancak tarihsel süreçte, özellikle yeni teknolojilerin gelișmesiyle birlikte teknolojinin bir toplumsal olgu olmasının yanında toplumsal bir 'aktör' olarak ele alınabileceği düşüncesi bu atfedilmiş radikallikten uzaklaşmaya başlamıștır. Her ne kadar sosyoloji alanında teknoloji üzerine yapılan çalışmalar son dönemde hız kazanmakla birlikte, sosyolojinin teknolojiye ilgisi, en azından akademik programlar içinde oldukça sınırlı bir düzeyde kalmıştır. Bu çalışma sosyolojinin teknoloji ile olan ilişkisinin kuramsal ve tarihsel bir izleğini çıkarmak ve teknolojinin aslında sosyolojinin kuruluşundan itibaren merkezi bir rolde olduğunu görünür kılmayı amaçlamaktadır.

\section{A B S T RAC T}

Even tough technology, from the most primitive tools to complex digital technologies, has been a central component of human existence, its theoretical status within sociology is often neglected, or reduced to a secondary place. From classical sociology to the recent theories, the relationship that mainstream sociology has established with technology has mostly been to consider technology as a human product and not as an actor in the production of sociality and stabilization of the social structure, but as a tool within human-to-human relationship. The idea that technology can be a social actor has mostly remained on the fringes of sociology as a radical idea. However, in the contemporary world, especially with the development of new technologies such as internet, robotics, and artificial intelligence and so on, the idea that technology, besides being a social phenomenon, must also be considered as a social 'actor' has begun to move away from this attributed radicalism. Although studies on technology in the field of sociology have gained momentum recently, sociology's interest in technology has remained at a very limited level, at least within academic programs. This study aims to reveal theoretical and historical paths of sociology's relationship with technology and to make it visible that technology has actually played a central role since the foundation of sociology.

\footnotetext{
*1 Yazar İletişim/ Corresponding Author: Emin Baki Adaş (Doç. Dr.), Aydın Adnan Menderes Üniversitesi, Fen-Edebiyat Fak., Sosyoloji, Aydın, Türkiye 凶eminadas@adu.edu.tr

*2 Borabay Erbay (Arş. Gör.), İzmir Ekonomi Üniversitesi, Fen-Edebiyat Fak., Sosyoloji, İzmir, Türkiye $₫$ borabay.erbay@ieu.edu.tr

Kaynak Gösterimi/ Citing This Article: Adaş, E. B. ve Erbay, B. (2021). Toplumsallığın Kurucu Aktörü Olarak Teknoloji: Eleştirel Bir Değerlendirme. Sosyolojik Bağlam Dergisi, 2(3), 99-114. doi:10.52108/2757-5942.2.3.7
} 


\section{Giriș}

Teknolojinin günümüzde üretim, iletişim ve ulaşım gibi hayatın makro düzlemlerinden, gündelik hayatın mikro düzlemine kadar yaşamın her alanında etkisini yakından deneyimlediğimiz bir güç haline geldiği söylenebilir. En ilkel aletlerden karmaşık üretim sistemlerine, radyodan televizyona ve bugün hepimizin hayatında reddedemeyeceğimiz bir yeri olan cep telefonu, internet gibi dijital teknolojiler hayatımızın her alanını biçimlendiren, etkileyen ve belirleyen bir niteliğe sahiptir. İnsan varoluşu ile bu denli yoğun bir ilişkisi olan teknolojinin sosyoloji tarafından ele alınmaması elbette düşünülemez. Nitekim, sosyolojinin teknolojiye olan ilgisinin ilk kurucu metinlerde izlerini sürmek mümkündür. Saint Simon'un "endüstriyel toplum," Comte'un "pozitivist toplum," Durkheim'in "mekanik/organik toplum," Weber'in rasyonel eylemin biçimlendirdiği "bürokratik-teknokratik toplum" tasavvurlarının merkezinde bilimsel ve teknolojik gelişmelerin yeni toplum kavramsallaştırmasının önemli bir parçası olduğunu söyleyebiliriz. Belki tüm bu klasik kuramcıların çok daha ötesinde teknolojiyi kendi kuramsal dizgesinin merkezine yerleștiren düșünürlerin bașında Karl Marx gelmektedir. Marx'ın toplumsal çözümlemesinin kilit kavramı olan üretim tarzı, üretim ilişkileri ve üretici güçlerin tarihsel olarak farklı bileşimlerini tarif eder ve Marksizm açısından üretici güçler (teknoloji) hem emek sürecinin niteliğini ve dönüşümünü, hem de sınıf-içi ve sınıflar-arası ilişkileri anlamda kilit rol oynar.

Günümüzde de sosyal bilim alanında yoğun tartışmalara konu olan modernite, post-modernite, risk toplumu, küreselleşme gibi yeni kavramsallaştırmalarda da, açık ya da örtük bir biçimde, teknolojik olguların toplumsallığın dönüşümünü tanımlamada merkezi olduğu söylenebilir (Beck, 2011; Giddens, 2011; Lyotard, 1984; Baudrillard, 2016.). Ayrıca, teknoloji sadece modern toplum içerisindeki kırılma veya kopuşların kavramsallaştırmasında değil, toplumlar arasında karşılaştırmada, toplumları hiyerarşik olarak sınıflandırmada da karşımıza çıkar. Örneğin, Michael Adas İnsanın Ölçüsü Olarak Makine: Batılı Hakimiyet İdeolojileri adlı klasik çalışmasında Batı'nın Batıdışı toplumlar üzerindeki üstünlüğünü ve kimliğini inşa etmede bilim ve teknolojinin nasıl merkezi bir konuma geldiğini analiz eder. Adas'a göre, 18.yüzyıldan itibaren Bat kendi kimlik inşasında ve öteki üzerindeki hegemonyasında, din-merkezli üstünlük tanımından teknoloji-merkezli üstünlük anlayışına doğru bir dönüşüm geçirmiştir. İlginç bir şekilde Batı-dışı toplumların da Batı ve kendilik algısında teknoloji üzerinden farklılığı içselleştirildiği görülmektedir†. Kısaca özetlemek gerekirse, teknoloji toplumlar ve kültürler arası kıyaslamadan sınıf ilișkilerine, siyasal iktidarın toplum üzerindeki denetiminden toplumsal dönüşümlere, gündelik hayatta insanlar arasındaki ilişki biçimlerinden insan-doğa arasındaki etkileşimlere kadar yaşamın her alanında maruz kaldığımız, kullandığımız, yaşamı anlamlandırdığımız bir güçtür.

Teknoloji insan yaşamının bütün alanlarında bu kadar merkezi bir öneme sahip olmasına rağmen, teknolojinin toplumsallığın kurucu bir momenti olarak doğrudan bir araștırma konusu haline gelmesi ancak yakın dönemde olmuștur. Her ne kadar sosyolojinin klasik kurucu metinlerinde toplumsal süreçlerin anlamlandırmasında, insanın insanla ilişkisinde teknoloji dışsal/nesnel bir olgu olarak görünürlüğe sahip olsa da teknolojinin doğrudan bir araştırma alanı olarak toplumsal yapının etkin bir faili olarak kavramsallaştırılması son yıllarda teknolojik gelişmelerin toplumsal ve doğal yaşam üzerinde artan etkisinin önem kazanması ile birlikte ortaya çıkmıştır. Özellikle, yapay zekâ ve akıllı robotlar vb. gibi teknolojilerin daha önce hiç almadığı bir biçime büründüğü günümüzde teknoloji ve sosyolojinin arasındaki bağın nasıl kurulabileceği en temel sorun alanlarından biri olarak ivedilikle yeniden gündeme alınmalıdır. Bu bağlamda, bu çalışma sosyal teoride klasik metinlerden başlayarak günümüze kadar teknoloji üzerine düşünmenin izlerini eleştirel bir perspektiften ele almayı amaçlamaktadır. Özellikle Türkiye sosyolojisinde öğretim programlarında teknoloji üzerine ders ve okumaların yok denecek kadar az olması, hem de teknoloji alanındaki araștırma ve tartışmaların yakın zamana kadar sosyolojinin kıyısında yer alması tespitinden hareketle, bu makale Türkiye sosyolojisindeki bu boşluk üzerine düşünmeye de bir katkı sunmayı amaçlamaktadır. Çalışmanın temel iddiası, teknolojinin toplumsallığın temelinde bir "aktör" olarak ele alınabileceği düșüncesini savunan bilim ve teknoloji çalıșmaları ekolünün "sosyo-teknik bir sistem" olarak toplum

† Mehmet Akif Ersoy’un İstiklal Marşı'nın bir dörtlüğünde şiirsel bir biçimde ifade ettiği “Garbın afakını sarmışsa çelik zırhlı duvar/ Benim iman dolu göğsüm gibi serhaddim var" mısraları Batı'nın teknolojik üstünlüğüne karşıt olarak konumlandırılan iman üzerinden Batı medeniyetinin değerini sorgular. 
kavramsallaştırması ve "aktör ağ teorisinin" günümüzde teknoloji, insan ve doğa arasında hızlanan karmaşık etkileşimleri düşünme açısından önemli teorik açılımlar sağladığıdır.

\section{$2 \quad$ Sosyoloji Klasiklerinde Teknolojinin İzini Sürmek}

Saint Simon, modern toplumu tanımlamada teknolojinin merkezi rolünü fark eden ilk sosyologlardan biridir. Saint Simon, ütopik bir biçimde kaleme aldığı endüstrileşme ideolojisinde metafiziğin karşısına örtük bir biçimde de olsa teknolojiyi koyar. Onun yarattığı ütopyada yeni hâkim sınıf olarak endüstriyel sınıf vardır. Bu sınıf, bilim insanları ve mühendislere özellikle vurgu yapılmakla beraber, toplumda üretici bir konumda olan tüm grupları kapsayan bir sınıftır. Bu sınıfın doğal yöneticileri ise bilim insanları ile birlikte endüstriyel işlere hâkim gruplar olacaktır (Saint Simon, 1975:158-161). Saint Simon ideal toplum tasavvurunda teknolojiye vurgu yaparken, aynı zamanda teknokratik bir toplumun inşasına da çağrı yapmaktadır. Saint Simon'un toplum tasavvurunda teknoloji metafiziğin yerini alırken, teknolojinin gücünü elinde tutan endüstriyel sınıf da ruhban sınıfının ve feodal iktidar sahiplerinin yerini alacaktır (Saint Simon, 1964:70). Teknokrasinin özellikle de 20. ve 21. Yüzyıllardaki yükselişi düşünüldüğünde, Saint Simon'un toplumun bilim ve teknoloji üzerinde yeniden yapılanmasını önerirken bir yandan bilim, teknoloji ve toplumun iç içe geçmişliğini de keşfetmiş olduğu söylenebilir.

Kendisinin öğrencisi olan ve sosyolojinin kurucusu olarak nitelenen Auguste Comte'un düşüncesinde de bu izleri görmek mümkündür. Comte'un üç hâl yasası ve insanlık dini düşünceleri onun teknolojiye olan örtük ilgisini göstermektedir. Comte için toplumların teolojik ve metafizik hâllerini belirleyen ana kuvvet olan imgelemin yerini gözleme bıraktı̆̆ı pozitif hâl, endüstriyel gelişmenin tüm tahakkümüyle toplumsallığı belirlediği, yeni bir elitin ortaya çıkacağı ve hâkim sınıfı oluşturacağı bir döneme işaret eden, çocukluktan erişkinliğe bir insanın gelişimine benzetilebilecek bir ilerlemeci anlayışın ilk halkalarından biridir (Comte, 2009a:157). Burada Comte'un teknoloji ile olan ilgisi en çok insanlık dinini yayma görevini taşıyacağına inandığı bilimsel elit üzerinde kendini gösterir. Görevi toplumları metafizik üzerine kurulu dinlerden pozitivizm üzerine kurulu insanlık dinine döndürmek olan bu elitin temel karakteristik özelliği ise bilim ve teknolojiye olan hakimiyetidir (Comte, 2009b). Bilginin özünü metafizikten veya duyulardan arındırılıp deneye ve gözleme dayandıran Comte, insanlık dini düşüncesinde epistemolojinin temeline bilimi yerleștirirken aynı zamanda teknolojiyi de yerleştirmiş olur. Comte'un argümanının temelini, pozitivist epistemoloji üzerine kurulan insanlı dininin dünyaya hâkim olacağı görüşü, bir başka deyişle, bilim ve teknolojinin ilerleyişi ve bu ilerlemenin metafizik karşısında pozitivizme sağlayacağı avantajların beklentisi oluşturur (Comte, 2009a). Comte'un düşüncesinde teknolojiye açıktan bir ilgi olmasa da, pozitivist bilimin uygulanışı noktasında teknolojinin yeri ile birlikte düşünüldüğünde bilimin uygulama aracı olarak teknoloji düşüncesinin temelini attığı söylenebilir. Hocası Saint Simon gibi, Comte da metafiziğin karşısına modern bilim ve teknolojiyi koyarak yeni toplumun özünü onlar üzerine kurar.

Durkheim'ın düşüncesinde teknolojiye açıtan bir ilgi olduğunu söylemek pek mümkün değildir. Teknolojiye dair en temel düşüncesinde Durkheim, emeğin sahip olduğu üretim gücünün yalnızca sermayenin değil teknolojinin de durumuna bağlı olduğunu yazar (Durkheim, 1994:180). Basitten karmaşığa doğru giden toplumsal yapılarda karmaşıklaşan iş bölümünün sürdürülebilmesi için gerekli olan organik dayanışma kavramı, iş bölümü ve teknoloji arasındaki ilişki ile birlikte düșünüldüğünde, Durkheim'ın düşüncesinde teknolojiye olan örtük ilgi görünür hale gelir. Teknolojik gelişme ve mesleki farklılaşma, Durkheim'in organik dayanışma olarak tarif ettiği modern toplumun bütünleşmesinin en önemli unsurlarından biridir. Durkheim'ın düşüncesinde toplumda organik dayanışma geliştikçe toplum daha karmaşık bir hâl alır. Durkheim'ın temel tespiti ise bu karmaşık yapının sürdürülebilmesi bireyler arası karşılıklı bağımlılığı artıran bir iş bölümüyle mümkün olduğu yönündedir (Durkheim, 1994). Dolayısıyla modern teknoloji de üretim alanından çıkarak tüm toplumsal alanlar üzerinde etki göstermeye başlar. Durkheim'ın düşüncesi üzerine yapılan çalışmalarda da teknolojik az gelişmiş̧lik mekanik dayanışmanın hâkim olduğu toplumsal biçimlere, teknolojik gelişmişlik ise organik dayanışmanın hâkim olduğu toplumsal biçimlere karşılık gelmektedir (Pope \& Johnson, 1983; Müller, 1994). Dolayısıyla Durkheim'ın düșüncesinde teknolojiye açıktan bir ilgiye rastlanmasa da teknolojinin toplumsallaşmaya olan etkisinin tamamen yadsındığı da söylenemez.

Klasik sosyolojide Marx'tan sonra teknoloji fenomeniyle yakından ilgilenen isim Max Weber'dir. Weber, modern kapitalizmin neden Batı'da ortaya çıktığı sorusuna yanıt aradığı ve yoğun tartışmaya 
konu olan klasik çalışmasında, rasyonalleşmenin Batı'da modern toplumun gelişmesinin özünde olduğunu tespit eder. Weber açısından modernleşme, Reformasyondan başlayarak dinden, ekonomiye ve toplumun tüm alanlarına hâkim olan rasyonelleşme sürecidir. Onun için rasyonalleşme bir anlamda sistematikleşmiş ve rutinleşmiş eylemler bütünüdür. Weber teknolojiyi de bu düşünce üzerinde temellendirerek kapitalizm analizinin içine katar; temelde teknoloji tekniğin rasyonelleşmesi ve bilimin tekniğe uygulanmasıdır (Weber, 1975:155). Rasyonelleşme hem toplumsal hem ekonomik hayatı teknik bilginin temelinde düzenler, şeylerin teknik bilgisine ulaşmak onların taşıdığı büyüyü bozmanın, yani sekülerleşmenin de en temel nedenlerinden biridir. Bu bağlamda, Weber'in hem kapitalizm hem de bürokratikleşme analizlerinin önemli bir bölümünde teknoloji ve toplum arasındaki ilişkinin izlerini görmek mümkündür (Weber, 1958). Weber için cansız bir makine aklın nesneleşmiş biçimidir ve insanın iş hayatını özelleştirilmiş belirli yeteneklere, belirli bir iş bölümüne ve belirli bir hiyerarşiye göre düzenleyerek onu kendine tabi kllar (Weber, 1978:1402). Bu rasyonel kurallar etrafında düzenlenen toplumsal örgütlenme bürokratikteknokratik bir toplumsal organizasyonu da beraberinde getirir. Weber, bir taraftan rasyonelleşmeyi Batı'da modern dönüşümü gerçekleştiren bir toplumsal eylem biçimi olarak olumlarken, diğer taraftan uzmanlaşma ve teknokrasiye tabi olan toplumsal örgütlenmenin, bireyin tüm yaratıcı edimlerini ve iradesini denetim altına aldığı/alacağı bir dönüşüme doğru evrildiğini 'demir kafes' metaforuyla vurgular. Weber, bürokratik-kapitalist toplumda 'demir kafesin' makine üretiminin teknik ve ekonomik şartlarına bağlı olduğunu söylerken rasyonelleşme ve bürokratikleşmenin bilim ve teknoloji ile olan ilişkisine dikkat çekmekte olduğunu belirtmek gerekir (Weber, 1958:184).

\section{Sermaye ve Aklın Tahakkümü: Vasıfsızlașan İnsan}

Marx, toplumsal ve tarihsel değişimin merkezine teknolojiyi koyan ilk düşünürlerden biridir. Toplum çözümlemesinde teknolojinin yerini, emeğin vasfını dönüştüren bir güç olarak saptayan Marx için teknoloji, toplumsallaşmanın en belirleyici parçalarından biridir. Bilindiği üzere Marx'ın toplumsal yapı analizinin temelinde üretim tarzı kavramı vardır. Üretim tarzı, insanların ihtiyaçlarını karşılamada doğayı dönüştürmede kullandıkları araçları, bu süreçte kendi aralarında geliştirdikleri toplumsal iş bölümü, üretim ve bölüşüm ilişkilerini ve bu ilişkilerin sürekliliğini sağlayan siyasi ve toplumsal yapıları tarif eder. İktisadi ve toplumsal yapı tarihin belirli bir döneminde, belirli bir coğrafyada hâkim olan üretim tarzı etrafında örgütlenir. Üretim ilişkileri toplumu meydana getiren toplumsal sınıflar nezdinde gruplar arasındaki ilişki biçimini tarif ederken teknoloji ise üretici güçler kategorisinde nüfus ile birlikte kendine yer bulan tüm araçları ve emeği, dolayısıyla teknoloji ve makineleri kapsayacak bir biçimde ele alınabilir (Mishra, 1979:135). Marx'ın, klasik iktisadın ekonomi politik analizlerine temel eleştirisi, klasik iktisadın ekonomik süreçleri sınıflar arası çelişkileri ve çatışmaları göz ardı ederek tarih-dışı bir biçimde kavramasıdır (Marx, 2019:358). Oysa Marx'a göre, toplumsal değișim ve dönüșüm, yani toplumların tarihini anlamanın anahtarı sınıf mücadelelerini analiz etmekle mümkündür. Tarihsel olarak sınıflar arası çelişkiler her üretim tarzı içinde yeni üretici güçlerin ve ilişskilerin gelişimini biçimlendirerek toplumların iktisadi ve siyasi yapılarında köklü dönüşümlere yol açar. Her ne kadar Marx'ın toplumsal analizlerinde tarihsel olarak farklı üretim tarzlarının nitelikleri ve dönüşümleri üzerine değerlendirmeleri önemli yer tutsa da Marx'ın esas ilgisi modern toplumun iktisadi, siyasi ve kültürel yapısını belirleyen kapitalizmin analizidir. Marx açısından kapitalizmi kapitalizm-öncesi tüm üretim biçimlerinden ayıran en önemli özellik, üreticilerin üretim araçlarından 'özgürleşmesi,' veya üreticilerin üretim araçlarından koparllarak emek gücünün meta haline dönüşmesidir (Marx, 2019). Marx’a göre, kapitalizm genelleştirilmiş meta üretimine dayalı bir iktisadi sistemdir: Sadece insanların ihtiyaçlarına karşıllık gelen mal ve hizmetlerin piyasada kar karşılığında alınıp satılması değil, bizatihi emek gücünün kendisinin piyasa koşullarına tabi bir meta haline gelmesidir. Kapitalizm öncesi üretim tarzlarında toplumsal olarak üretilen artı-değere ekonomi-dıșı zor mekanizmalarına dayalı olarak el konulurken, kapitalizmde artı değere el konulması üretim araçlarına sahip sermaye tarafından iktisadi mekanizmalara dayalı bir biçimde gerçekleştirilir (Marx, 2019).

Kapitalizmde artı-değerin sürekli ve artan bir biçimde yeni sermaye birikimine dönüşmesi göreli sömürü oranın artması ile, üretici güçlerin sürekli gelişimi ve emek sürecinde üreticilerin üzerinde artan denetimi ile mümkündür. Bu bağlamda, Marx üretici güçlerin gelişimini makine ve alet arasındaki farkı tartışmaya açarak başlar. Marx'a göre, alet ve makine arasındaki farka dair yaygın kabul gören aletin basit bir makine, makinenin ise karmaşık bir alet olduğu; ikisi arasındaki farkın ise, aletin gücünü insandan, makinenin ise insan olmayan kaynaklardan aldığı șeklinde yapılan açıllama toplumsal dinamiklerden uzak mekanik bir düşüncedir (Marx, 2019:358). Marx için makine 
ve alet arasındaki fark, emek sürecinde yarattığı sadece nicel değil nitel dönüşümde gizlidir. Makinenin emek sürecinde yarattığı dönüşüm üretimde uygulanan emeğin kuvvetinde değil, niteliğinde aranmalıdır (Marx, 2019:358). Kapitalizm-öncesi üretim biçimlerine, örneğin manifaktüre hâkim olan emeğin örgütlenmesi, henüz birbirleriyle değișebilir metalar hâlini almaktan uzak olan ve her biri kendine özgü bir değer taşıyan zanaat ürünlerini üreten, zanaatte yetkinliğin ve el emeğinin temel koşullardan biri olduğu, aynı zamanda mevsim koşulları, doğum-ölüm gibi doğal koşullara bağlılığı, insan yapımı koşullara olan bağlılığından daha yüksek olan insanî bir emek sürecini işaret eder (Marx, 2005:100-101). Bu anlamda, kapitalizm-öncesi emek süreci Marx için emeğin insanın kendini nesneleștirmesindeki araçsal konumuna işaret eder. Çalışan bir insan, dünya üzerinde bıraktığı etki üzerinden kendi özünü nesneleștirir; bu noktada emek insanın kendini gerçekleştirmesinin bir aracı olarak tanımlanabilir (Wending, 2009:30). Buna karşllık, üretim aracı, sermayenin denetimine girmesiyle beraber başkalaşım geçirir ve sermayenin organik bir bileșeni hâlini alır. Marx için makineleşme bu başkalaşım sürecinin son noktasıdır (Marx, 2016:5). Marx, üretim araçlarının doğrudan biçimlerini kaybettikçe -yani üretim sürecinde kullanım değeri üzerinden değerlenen parçalar hâline geldikçe- sabit sermayeye dönüștüklerini vurgular. Dolayısıyla, makine de üretim süreci içerisinde değeri kendinden menkul olan, değişim sürecine katılmayan sabit sermaye olarak anlam kazanır (Marx, 2016:10). Bu durumda, iş bölümünün bu artışıyla, işçi yalnızca kapitalistle veya diğer iş̧̧ilerle değil, makineyle de rekabete girmek durumundadır (Marx, 2018:22). Aslında Marx'ın teknoloji çözümlemesinin temel ilgisi de bu rekabetin iş̧̧i sınıfı üzerinde yarattığı yıkıcı etkinin ortaya koyulmasıdır.

Teknolojinin sermaye tarafından kullanımı, emeğin niteliğinin yanında niceliğine olan gereksinimi de değiştirir. Emeğin yapısındaki bu değişme, iş̧̧iyi üretim sürecinin aktif bir aktörü olmaktan çıkararak bir gözcü ve düzenleyiciye dönüştürür (Marx, 2016:27) veya işçi sayısının gerekenden fazla olmasıyla birlikte işsizlikle karşı karşıya bırakır (Marx, 2018:18). Dolayısıyla işçinin üretim sürecine dair herhangi bir yetkinliğe ve belirli bir fiziksel güce sahip olması gerekliliği ortadan kalkar ve böylece daha önce işgücüne dahil olması mümkün olmayan nüfusun da -kadınlar ve çocuklarüretim sürecine dahil olması anlamına gelir (Marx, 2019:378). İşgücüne katılımda yaşanan bu büyük artış ise emeğin değerini düşürerek ve işsizliği yükselterek bir işsizler kitlesi, Marx'ın tanımıyla yedek iş gücü ordusu yaratır (Mishra, 1979:143). Makineleşmenin iş̧̧iye etkisi yalnızca bununla sınırlı değildir. Makineleşme aynı zamanda iş gününü sürekli olarak uzatan bir etkidedir; makinenin işçi gibi yaşamsal ihtiyaçlarını karşılama zorunluluğu yoktur. Aynı zamanda sermaye olarak kapitalistin kişiliğinde bilinç ve irade sahibi olan makine, zorunlu hâller dışında işe direnmez (Marx, 2019:386). Dolayısıyla makine -işçiye oranla üretim kapasitesinin de kat be kat yüksek olduğu düșünüldügünnde- 'işlevsiz' kaldığı her an sermayeye büyük bir maliyet oluşturur. Dolayısıyla makinenin sürekli işler hâlde olması, sermaye için arzulanır bir hâl alır ve makine başındaki işçinin iş günü buna istinaden sürekli uzar (Marx, 2019:389). Nihayetinde, makineleşme emek ve sermayenin masaya özgür biçimde oturdukları durumu tümden yıkarak gücü sermayeye verir (Marx, 2019:381). Makinelerin ortaya çıkışından sonra emek ve sermaye arasındaki mücadele, bir sermaye aracı olarak makine ile işçi arasındaki mücadele biçiminde görülür. Ancak zaman içinde işçi sınıfı mücadelesinin makinenin kendisiyle değil, onun kapitalist kullanımı ile olduğunu kavramasıyla mücadele esas biçimini alacaktır. (Marx, 2019:408-412).

Marx'ın doğa bilimleri ve doğa bilimlerinin etrafında yapılanmış olan teknolojiye dair düşüncelerinin, yani teknolojik birikim ve ilerlemenin kendinde değil, kapitalizm ve sermaye ile girdiği ilișkide kazandığı anlamın eleştirilmesi gereken esas şey olduğuna yönelik fikirleri Frankfurt Okulu tarafından geliştirilerek bir adım ileri taşınmıştır. Frankfurt Okulu'nun temel bilim ve teknoloji eleştirisi Marx'ın izlediği yoldan bu noktada ayrılarak aklın araçsallaşması çevresinde gelişmiştir (Collin \& Pedersen, 2015:46). Kitle kültürünün ortaya çıkmasını mümkün kılan ve maddi altyapısını oluşturan teknolojik gelişmelerin araçsal aklın meşruiyetini yaygınlaştırdığı tezi Frankurt Okulu düşünürlerinin önemli tespitlerinden biridir. Teknolojinin toplum ile ilişkisinde aldığı biçim kültür endüstrisini ve kitle kültürünü yaratmaktaki etkisinde ortaya çıkar. Kültür endüstrisi kendini bir anlamda teknolojik ilerlemenin kaçınılmaz [ve iyi] sonucu olarak sunar ve tüketimin aslında kültür endüstrisinin belirli ve sınırlı üretiminin bir zorlaması olduğunu gizler (Adorno, 2014:49). Kültür endüstrisinin tahakküm araçları her yerde aynılığı bulaştırırken, bunu teknolojinin gücünü kullanarak gerçekleştirirler. Adorno'nun radyo ve telefon arasında yaptığı ayrım bu fikrini net bir şekilde gösterir. Bir iletişim aracı olan telefon insanın özne rolünü oynamasına izin verirken, bir sonraki aşamada radyo "tüm insanları farklı kanallarda yayınlanan aynı programların dinleyicileri 
hâline getirirken" (Adorno, 2014:49) bir anlamda demokratik bir yanılsama ile herkesi kültür endüstrisinin içine çeker. Kültür endüstrisinin en önemli aktörleri kapitalizme organik bir biçimde bağlıdır (Adorno, 2014:51).

Frankfurt Okulu temsilcilerinde teknolojiyi çözümlemesinin en önemli temsilcilerinden biri de Herbert Marcuse'dir. Marcuse araçsallașan șeyin yalnızca akıl olmaktan çıkıp, insanın da araçsallaştığı teziyle eleştiriyi bir adım öteye taşır (Collin \& Pedersen, 2015:47). Akıl bir kültürel form hâlini almıştır ve yalnızca bir yerden değil, birçok yerden insanı tahakküm altına almaktadır. Teknolojik akıl, teknolojinin insan hayatının her alanına dahil olmasıyla birlikte insanın ve toplumsal hayatın bir yeniden-düzenlenmesine işaret eder. Teknolojinin bilgisi yeni bir bilgidir ve bu yeni bilgi teknolojik aletlerin şifrelerinin çözümlenmesiyle gündelik hayatı devam ettirilebilir kılar; teknolojik akıl bu süreçlere uyum sağlamaya çalışan insanın aklıdır (Marcuse, 1998:139). Akıl teknolojinin güdümüne girdikçe akıl olmaktan çıkarak teknolojinin bir aracı hâlini alır ve bunun neticesinde yeni bir kültürel forma dönüşür (Feenberg, 2017:5). Bir kültürel form olarak teknolojik akıl, kültür endüstrisine benzer biçimde özgür olmadığının farkında olmayan itaatkâr bir kitleyi yaratmanın anahtarıdır. Bu itaatkârlık ve özgürlük yokluğunun kimin işine geleceği ise bellidir: kapitalizmin zaferinin gerçekleşebilmesi için, şirketlerin daha üretken çalışabilmesi ve eşitsiz ekonomik güce sahip aktörler arasındaki rekabetin [anlamlıymışçasına] sürdürülebilmesi, [dolayısıyla buna engel olacak olan] bireyliğin geri çekilmesi ve baskılanması gerekir (Marcuse, 2007:3).

Marcuse teknolojik aklın insan üzerindeki tahakkümünü üç eleştiri üzerinde temellendirir. Bu eleştirilerden ilki işçi sınıfının kapitalizm karşısındaki direncini azaltmanın bir aracı olarak kitlesel medya ve tüketimin rolüdür. İkinci eleştiri, kültürel bir form hâlini alan teknolojik aklın sınıf çatışmalarını teknik problemlere indirgeyici etkisidir. Üçüncü eleştiride ise teknolojinin ve teknolojik tasarımların yukarıdan aşağıya kontrolü pekiştirip kapitalizmi güçlendirici etkisini buluruz (Feenberg, 2017:7). Böylece, özellikle Marcuse'nin teknolojiyi ele alış biçimi özelinde Frankfurt Okulu'nun teknoloji ve toplum üzerine tartışmalarının yönü ortaya çıkar. Frankfurt Okulu'nun, Marx'ın teknoloji ve teknolojik aletlere yönelik yaklaşımındaki temel tutumu olan şeylerin değeri kullanım biçimlerine göre ölçülür anlayışını bir anlamda terse çevirerek, problemi şeyleri önceleyenin -araçsal aklın- karakterine çektiklerini görebiliriz. Frankfurt Okulu'nun teknoloji eleştirisinin temelinde araçsal akla uygun inşa edilmiş her şeyin özünde insanî olanı baskılayacak ve akıl-dışı kılarken yeniden-üretilmesini sağlayacak olduğu fikri görülmektedir. Zaten, ileri sanayi toplumu da akıl-dışı bir toplumdur (Marcuse, 1998:146).

\section{Fenomenoloji ve Teknolojinin Özü Tartışmaları: Makine Tarafsız Mıdır?}

Doğrudan teknolojinin doğasına ilişkin ilgi, bilim ve teknolojideki gelişmelere paralel olarak özellikle Avrupa ve ABD'de akademilerinde 20. Yüzyılın ikinci yarısından itibaren hız kazanmıştır. Alman filozof Martin Heidegger'in teknoloji üzerine felsefi çözümleri, bilim ve teknoloji çalışmalarını hem felsefenin hem de sosyolojinin temel çalışma alanlarından biri haline getirmiştir. Fenomenoloji teknoloji üzerine ilk sistematik felsefi düşünme girişimi olarak değerlendirilebilir. Fenomenolojide teknoloji sorunu teknoloji ile insan arasındaki ilişki üzerine odaklanır. Bu bağlamda, teknoloji gerçekliği algılamanın ötesinde yorumlamanın da bir biçimi olarak ele alınır. Fenomenolojik bir bağlamda teknoloji, gündelik hayatımızı [ve dolayısıyla tüm anlam dünyalarımızı ve eylemlerimizi] manipüle eden bir güç olarak ele alınmaktadır (Feenberg, 2010; Ihde, 1979; Ihde, 1990). Burada fenomenolojik yaklaşım içerisinde öncelikle modern teknoloji felsefesinin kurucusu olarak kabul edilen Martin Heidegger ve Heidegger eleştirisiyle teknoloji felsefesinin en önemli isimlerinden biri olan Don Ihde'nin görüşlerine bakmak yerinde olacaktır. Heidegger için önemli olan teknolojinin aldığı biçimler ve gelişmişlik düzeyinden ziyade, teknoloji ile kurduğumuz ilişkinin biçimi, bizim teknolojiyi algılama biçimimiz ve teknolojinin insan eylemini manipüle etme biçimleridir. Heidegger teknolojinin iki algılanış biçiminden doğan çifte bir anlamı olduğunu belirtir: Bunlar bir araç olarak teknoloji ve bir insan eylemi olarak teknolojidir. Teknolojinin bu algılanma biçimlerini araçsal ve antropolojik algılanma biçimleri olarak niteler (Heidegger, 1977:4). Teknolojinin bu iki algılanış biçimi birbirleriyle iç içe geçmiştir. Teknolojik araçlar belirli amaçlar taşırlar -araçsal anlam- ve bu araçların üretimi ve kullanımı elbette insan eylemidir -antropolojik anlam- (Heidegger, 1977:4).

Heidegger teknolojinin bu anlamlarının yanlıș olduğunu iddia etmez. Aksine bu anlamların doğru olduğunu belirtir; her iki anlam da teknolojinin ne olduğunu tanımlamakta yeterlidir (Heidegger, 1977:5). Ancak bu anlamlar fazlasıyla yerleşmiş anlamlardır ve teknoloji ile insan arasındaki ilişkiyi açıklamakta yetersiz kalırlar. Teknolojinin bu anlamları, insanın onunla kurduğu ilişkiyi örten bir 
işlevdedir ve teknoloji ile ilgili esas mesele onu en ustaca kullanabilme kapasitesini elde etmeye indirgenmiş olur. Böylece teknolojiye bir ruh atfetmiş oluruz ve gerçek soruyu -yani teknoloji ve insan arasındaki ilişki sorusunu- kaçırırız (Heidegger, 1977:5). Heidegger teknolojinin tanımını yapmaktan ziyade teknoloji ile insan arasındaki ilişkiyi anlamlandırmanın peşindedir, dolayısıyla o, bu iliş̧inin özünü tartışmaya açar ve fenomenoloji bu noktada devreye girer. Heidegger için modern teknoloji, metafiziğin başlangıcıdır. Burada yaptığı ayrımda [modern] teknoloji ile [geleneksel] techné arasındaki karşıtlı̆̆ kullanan Heidegger, en basit biçimiyle, technénin şeylerin özünü ortaya çıkarırken aynı zamanda gerçeği ortaya çıkaran yanının modern teknolojide kaybolduğunu söyler. Modern teknoloji gerçeği ortaya çıkarmaktan ziyade örter (Turanl, 2017:2). Modern teknoloji doğaya akılcı olmayan bir biçimde meydan okur ve doğa [aslında olmaması gereken bir biçimde] teknoloji için hem bir kaynak hem de bu kaynakların depolandığı bir şey hâlini alır; böylece, [technéden ilerleyiş sürecinde] teknoloji doğanın ve şeylerin gerçekliğine ulaşmanın değil, bunu örtmenin bir aracı olur (Heidegger, 1977:14). Kısacası Heidegger için teknolojinin özü teknolojinin kendisinde değil, insan ile olan ilişkisinin incelenmesiyle ortaya çıkarılabilir. Teknoloji, içinde bulunduğu çağın [verili kabul edilen] gerçekliğini çerçeveler, dolayısıyla teknolojinin çerçevelediği gerçeklik gerçeğin kendisi değil, onun süzgecinden geçmiş olan bir modelidir (Mertel, 2020:467).

Heidegger'i düşüncesindeki özcülük üzerinden eleștiren Don Ihde'ye göre ise teknoloji üzerine düşünmenin makul biçimi, metafiziksel bir teknoloji tahayyülünden değil, gündelik hayat ve yaşam dünyamızdan yola çıkan bir düşünme biçimi olmalıdır (Ihde, 2010:102). Ihde bir post-fenomenolojist olarak konumlandırılabilir ve teknoloji ile yaşam dünyası arasındaki bağı soyut teknoloji teorilerine yeğler pozisyondadır (Scharff, 2012:298). Ihde'nin teknolojiye temel ilgisi, teknolojinin kendisi değil, teknolojinin dünya ile insan arasındaki bağı kurmaktaki işlevi üzerinedir. Bu bağlamda teknoloji ile insan arasındaki ilişkiler, aslında teknoloji, insan ve dünya arasındaki ilişkilerdir (Nørskov, 2015:190). Ihde, insan, teknoloji ve dünya arasındaki ilişkileri farklı biçimlerde kategorize etmiştir. Bu kategorizasyon insan ve teknolojinin arasında kurulan bir olma hâliyle ortaya çıkan cisimleşmiş ilişki, teknolojinin dünya ile bir olma ilişsisi kurduğu ve insanın bu ilişkiden süzülenleri yorumladığı hermenötik ilişki, insan ile teknolojinin direkt ilişkisinde dünyanın bir arka plana dönüştüğü, bir karşıllklılık hâli üzerinde yapılanan ötekilik ilişkisi ve teknolojinin insan eylemi ile deneyimlerine bir arka plan sağladığı bir iliş̧i biçimi olan arka plan ilişkisi olarak özetlenebilir (Ihde, 1990; Ihde, 1979). Söz gelimi, bir cep telefonuyla konuşurken aslında telefonun kendisiyle değil, hattın diğer ucundaki kişiyle konuşmuş oluruz, ancak burada insan ve cep telefonunun oluşturduğu bir olma hâli yeni bir biçimin cisimlenmesidir. Bir MRI cihazının doğal bir fenomen olan bedenin bir temsilini bir doktora sunması ve doğal bir fenomeni bu temsil üzerinden yorumlayan bir doktor hermenötik ilişkiye örnek olabilir. Ötekilik iliş̧isine bir örnek, yiyecek almak için bir otomatla iliş̧i kuran bir insan, veya yeni teknolojilerde insan-robot ilişkileri olarak gösterilebilir. Gündelik hayattaki eylemlerimiz ve deneyimlerimizi etkileyen arka plan ilişkisine bir örnek ise sıcak havalarda soğuk, soğuk havalarda sıcak bir iklimlendirme sağlayan bir klimanın insan ile direkt temas sağlamadan onun gündelik deneyimlerine etki etmesi olabilir. Mevsime göre sıcak/soğuk dengesi ayarlanamazsa insanın gündelik deneyimi kötüye gidecektir, şayet bu denge ayarlanabilir ise insan gündelik deneyiminde memnun bir hâlde olacaktır.

Fenomenolojik teknoloji yaklaşımı temelde şöyle özetlenebilir: teknoloji gündelik hayatımızın o kadar içine girmiştir ki, teknolojik aletler bedenimizin birer parçası hâlini alırken, dünyayla olan ilişkimiz teknolojinin süzgecinden geçerek kurduğumuz bir ilişkiye dönüşür. Teknoloji, insan ile dünyanın birbirleriyle olan ilişkisini manipüle ederken, insanın dünyayı algılayıșı [ve bu algılayışın bir yansıması olarak] kendini algılayışını da manipüle eder (Ihde, 1979:5-6). Dolayısıyla teknolojinin fenomenolojik ele alınışı teknoloji ile insan arasındaki ilişkiye odaklanarak, teknolojinin özünü kendi içerisinde değil, insan ve dünya arasındaki ilişkiyi manipüle etmesinde aramaktadır.

\section{Bağlamların Kopuşu, Yeni Özneler ve Teknoloji}

1970 ve sonrası teknolojik gelişmelere paralel, başta gelişmiş ülkeler olmak üzere, Dünya'da iktisadi ve toplumsal yapıda köklü dönüşümler yaşanmıştır. Bu dönüşümlere değinmeden önce kısaca savaş sonrası döneme hâkim olan birikim rejimi ve toplumsal örgütlenmeye kısaca değinmekte fayda var. İki Dünya Savaşı arasında ortaya çıkan iktisadi ve toplumsal krizlere çözüm olarak Savaş sonrası dönemde Batı'da refah devleti, gelişmekte olan ülkelerde ise "ulusal kalkınma" modeli ekseninde yeni birikim rejimi ulusal sınırlar içinde kitlesel üretime ve iç talebe dayalı bir büyüme stratejisini gündeme getirmiștir. Bu dönemin hâkim üretim örgütlenmesi iş güvencesinin ve sendikal hakların 
güç kazandığı Fordist üretim modelidir. Sosyal hakların genişlediği bu dönemde, devlet destekli altyapı ve hizmetler sektörünün genişlemesi ile hem sermaye birikiminin arttırılması hem de işçi sınıfı radikalizminin sınırlandırılması hedeflenmiştir. Ancak, 1970'lerde baş gösteren petrol krizi ve daha da önemlisi örgütlü işçi sınıfının refah payının artması sermayenin karlılığı üzerinde önemli ölçüde baskıya yol açmıştr. Ortaya çıkan krize çözüm olarak neoliberalizm olarak adlandırılan yeni bir birikim modeli aşama aşama bașta Şili, ABD, İngiltere ve Türkiye olmak üzere gelişmiş ve gelişmekte olan ülkelerde başat politika seti olmuştur (Harvey, 2005). Kamu bütçesi içinde sosyal harcamaların sınırlandırılması, devletin küçültülmesi, kamu iktisadi teşekküllerinin özelleștirilmesi, çalışma hayatının esnekleștirilmesi, sendikasızlaştırma gibi ekonomiden, siyasete ve kültüre kadar köklü dönüşümlere yol açan neoliberalizm, sermayenin hem yerel hem de küresel ölçekte genişlemesini ve derinleşmesini beraberinde getirmiştir. Devlet kontrolündeki ekonominin rekabete açılması, büyük ölçekli özel sermaye yatırımlarının eğitim, sağlık, kentsel rant, tarımsal üretim (özellikle tohum geliştirme, gübre, tarım teknolojileri vs.) gibi yeni alanlarda teşvik edilmesi, yeni teknolojilerin de üretimini hızlandırmıştır. Özellikle, üniversitelerin sanayi ile proje bazlı iş birliğine yönlendirilmesi bilginin hızlı bir biçimde metalaşması beraberinde getirmiş ve teknolojik alanda önemli sıçramalar yaşanmıștır. "Enformasyon/bilgi toplumu" gibi yeni kavramsallaştırmalar aslında sermayenin bilgi ve iletişim teknoloji alanlarında artan yatırımı ve bu alanın ekonominin örgütlenmesinde ve toplumda yeni bir güç haline geldiğine işaret etmektedir (Beniger, 1986; Webster, 2006). Mobil telefon, bilgisayar, internet gibi iletişim teknolojileri, mal ve para akışlarının yerel sınırlılıklar ve 'katılıklardan' kurtularak küresel ölçekte örgütlenmesini, akışını ve etkisini kolaylaştırmıştır. Benzer bir biçimde ulaşım teknolojilerinin hız kazanması hem mal ve hizmetlerin hem insan hareketliliğinin ulus aşırı bir biçimde gerçekleşmesini sağlamıştır. "Zaman-mekân sıkışması" olarak da tanımlanan küreselleşme (Giddens, 1991; Harvey, 2005), ulaşım ve iletişim teknolojilerinin alt yapısı üzerine șekillenen birbirinden uzak mekân ve zamansallıkların birbirine iktisadi, siyasi ve kültürel olarak eklemlenmesi ve birbirini etkilemesini tarif eden yeni bir toplumsal durumu ifade eder. Manuel Castells (2009) 1970 sonrası ortaya çıkan bu yeni toplumsal durumu, toplumların ve toplumsal grupların enformasyon teknolojileri üzerinden etkileşim içine girebilmesini "ağ toplumunun yükselişi” olarak tarif eder. Üretim sürecinin örgütlenmesi de teknolojik gelişmelerin sayesinde küresel bir niteliğe dönüşmüştür. Mal ve hizmetler üretiminin farklı aşamalarının birbirinden farklı mekanlarda gerçekleşmesi, yani üretimin mekânsal olarak parçalanması üreticilerin güvencesizliğini de derinleștirmiştir. Sermayenin küresel ölçekte sürekli daha ucuz işgücü arayışı çalışanlar arasında dayanışmadan daha ziyade rekabeti derinleștirmiştir. Otomasyon teknolojilerinin gelişmesiyle birlikte ortaya çıkan kitlesel işsizlik sadece mavi yakalı çalışanların değil, beyaz yakalı çalışanların da küresel ucuz iş gücü ile rekabet etmek durumunda kaldığı, Guy Standing'in (2011) deyimiyle 'prekerleşmeyle' karşı karşıya kaldığı yeni kapitalizm, (Noble, 2011) tüm çalışanların güvencesizliğini norm haline getirmiştir. Bu bağlamda, geleneksel sınıf siyasetinin zayıflaması (Gorz, 1987), siyasal alanda hem dini, etnik kimlikler etrafında, hem de sermaye ve teknolojinin doğa ve yaşam alanlarına artan müdahalesi ekoloji ve çevre hareketi gibi parçalı yeni toplumsal hareketlerin ortaya çıkmasına yol açmıştır (Melucci, 1980; Habermas, 1981; Touraine, 1985).

İktisadi, toplumsal ve kültürel alanda yaşanan bu değişimler aynı zamanda sosyal bilimler içinde epistemolojik tartışmaları da derinleștirmiştir. Bir taraftan bildiğimiz anlamda modernitenin sonunu ilan eden post-modernite, diğer tarafta ise değişimi tespit etmekle birlikte sürekliliklere işaret eden geç modernite tartışmalarının bilim ve teknolojinin yeni toplum kavramsallaştırmalarının merkezinde yer aldığını belirtmek gerekir. Zira, postmodernizmin birçok alanda modernitenin sonunu tahayyül etme çabası ve onun inşa ettiği dünyaya eleştirel bir yaklaşım olduğu düşünüldüğünde, modernitenin bilimi ve teknolojisini de eleştirel bir bağlamda ele aldığı söylenebilir; modernitenin sorgulanması ve [postmodern bakışın öne sürdüğü şekliyle] yaşadığı meşruiyet krizlerinden modern bilim ve teknoloji de payına düşeni alır (Heise, 2004:137). Aynı zamanda bilimsel ve teknolojik ilerlemeler insanlık tarihinin daha önceki dönemlerinde hiç olmadığı kadar hızlanmasından ve teknolojiyle kurulan iliş̧inin bir uzmanlık ilişkisinden çıkıp gündelik hayata hâkim bir ilişki biçimi olmasından dolayı [bilimsel ve teknolojik] bilginin yeni biçimleri de modern sonrası dönemde mercek altına alınmıştır (Heise, 2004:138). Bu alandaki tartışmaları iki teorik kamp etrafında değerlendirmek mümkündür: Bir tarafta geç modernite, risk toplumu gibi kavramsallaştırmalar altında yeni toplumsal durumu ve bu süreçte bilim ve teknolojinin konumunu ele alan Beck ve Giddens gibi düşünürler, diğer tarafta toplumsal ve siyasal alanın radikal dönüşüm 
geçirdiğini iddia eden Lyotard, Jean Baudrillard, ve Foucault gibi post-yapısalcı, post-modern düşünürler.

İlk olarak modern bilim ve teknolojinin sert bir biçimde eleștiriye tabi tutulmasına işaret eden tarafı ele alacak olursak, bu hususta en önemli fikirlerin Ulrich Beck tarafindan dile getirildiğini söyleyebiliriz. Beck'e göre modernite bir anlamda kendi ürettiği riskleri açıklayamaz bir hâldedir ve bu risklerin hâkim olduğu yeni toplumsallaşma biçimi olan risk toplumu, modern-sonrası dünyayı karakterize eden yeni bir durumdur. Beck, postmodernizm fikrine şüpheyle yaklaşarak, modernitenin sona ermediğini, sona erenin basit modernite olduğunu ifade eder. Beck'e göre, günümüz dünyasını karakterize eden yeni toplumsal durum refleksif modernite olarak tanımlanabilir (Beck, 2011). Beck'e göre refleksif modernite ve basit modernite arasında temel benzerlikler mevcuttur: her iki dönemde de yaşam koşullarını değiştirecek müdahaleler olmuştur. $\mathrm{Bu}$ müdahaleler üretici güçler, piyasa, mülkiyet ve iktidar ilişkilerinin çeşitli aşamaları ile ortaya çıkmış ve değişiklikler göstermişlerdir (Beck, 2011:73). Bu ilişkilerde yaşanan değişimler refleksif modernitenin toplumsal örgütlenme biçimi olan risk toplumunun ikili karakterini gösterir niteliktedir: yeni toplumsallığın temelinde doğanın ve geleneğin sonu vardır; doğa ile ilgili sorular değişmiş ve doğa bize ne yapabilir sorusunun yerini biz doğaya ne yaptık sorusu almıştır. Gelenek ise refleksif modernite öncesinin güvenli yaşam biçimleri ve bu yaşam biçimlerinin yollarının artık hayatını yönlendiremediği noktada bireyin seçimleri ve bu seçimlerin riskleri üzerine düşünmesi gerekliliğine işaret eder (Beck, 1998:10). Tüm bu dönüşümün temelinde ise modernitenin biliminin ve teknolojik ilerleyişinin [klasik modernitedeki kutsal yerine istinaden] sorgulanmadan gelişmesi vardır. Bu gelişmeler modern dünyayı kendi yaratısı olan bilim ve teknolojinin ortaya çıkardığı riskleri açıklayamaz bir pozisyona getirmiş ve tüm toplumsallığımız kökünden değişmiştir. Riskler tüm dünyayı sarmış ve bu risklerin pençesindeki modern toplumlar bilime ve teknolojiye şüpheyle yaklaşılan yeni bir düzene geçmişlerdir; modernitenin yarattı̆̆ bilimsel ve teknolojik riskler, sınırları ve sınıfları aşan bir biçimde birleştiricidirler (Beck, 2011:49).

Beck'in düşüncesine yakın bir konumda olan Anthony Giddens'a göre de modern dünya "kontrolümüzden çıkmış bir dünyadır: Toplumsal değişme hızı önceki sistemlerdekinden daha yüksek olmakla kalmayıp, daha önceki toplumsal pratikler ve davranış biçimlerini etkileme derecesi ve kapsamlılığı da yüksektir" (Giddens, 2010:30). Modern dünyanın kontrolden çıkışında da teknolojinin etkisi olduğu barizdir. Her ne kadar Giddens'ın teknoloji ile ilgisi Beck kadar yoğun olmasa da, onun görüşünde de modernitenin zaman ve mekânsal bağlarını kopararak, toplumsal hayatı tahakkümü altına almasının teknoloji ile ilgisi olduğu açıktır. Modern-öncesi durumda zaman ve mekân, kişinin bulunduğu yer ile temelden bağlıyken, mekanik saatin icadı ve yayılmasıyla zamanın evrenselleşmesi ve birleşmesi örneğinde görüldüğü gibi (Giddens, 1991:17) Giddens için de teknolojik ilerleme küreselleşmenin ve modernitenin temelinde bir yerde durmaktadır.

Modern-sonrası düşüncesinde teknoloji çalışmaları, postmodernizm ekseninde, özellikle Fransız postyapısalcılığı içerisinde yukarıdaki anlamından farklı bir biçimde tartışılmıştır. Post-yapısalcılık ve temsilcileri, daha çok modern öznenin oluşumunda denetim ve disiplin mekanizmalarında teknolojinin yeri üzerine düşünmüşlerdir ve geç modernite savunucularından farklı bir biçimde teknolojiyi ele almışlardır. Örneğin Lyotard'a göre postmodern dönemde bilginin mahiyeti değişmiştir ve bu değişimde teknolojik değişmelerin rolü büyüktür. Teknolojik değişmenin bilgi üzerindeki iki temel etkisinden bahseden Lyotard, bunları araștırma ve bilginin yayılmasındaki etkileri olarak kategorize eder (Lyotard, 1984:4). Birinci etki, sibernetikler sayesinde siradan insanların da genetik ile ilgili fikirlere sahip olabilmesi şeklinde örneklenebilirken, ikinci etki ise makinelerin yayılması ve kullanımının herkese açılmasıyla bilgiyi edinme, sınıflama ve sömürme biçimlerinin değişmesi olarak gösterilebilir (Lyotard, 1984:4). Lyotard için bilgisayarlaşan toplumlar bilgisayarların dilini konuşurlar, böylece postmodernizmin gerçeklik söylemde inşa edilir biçimindeki temel iddiasıyla birlikte düşündüğümüzde, gerçeklik, postmodern dönemde bilgisayarın dili hâlini almıștır. Bilgi ve gerçekliğin ilişkisi üzerine gözlemlerinde bilginin metanın üretimindeki temel güç hâlini aldığını söyleyen Lyotard'ın (Lyotard, 1984:5). temel argümanını şu şekilde özetlemek mümkün görünmektedir: kültür, dijital teknolojiyle birlikte tıpkı kapitalist sistem gibi optimal performansın elde edilmesinin, yani en az girdiyle en çok çıktının alınmasının başat konumda olduğu bir șey hâlini almaktadır (Lyotard, 1984:44). Bir anlamda yeni dijital bir kapitalist kültürün resmidir onun çizdiği. 
Jean Baudrillard da teknolojiyi tarihsel olarak üçüncü simülakr dönemi olarak nitelediği simülasyon evrenini temeline konumlandırır. Ona göre simülasyon, bilgi, model ve sibernetik oyunlardan oluşan, mutlak denetimi hedefleyen bir simülakrdır ve aynı zamanda "bir köken ya da gerçeklikten yoksun bir gerçeğin modeller aracıllğıyla türetilmesidir" (Baudrillard, 2016:14). Bu noktada Baudrillard bir hipergerçeklik olarak simülasyondan bahsetmektedir. Bir simülasyonun en üst noktası olarak sanal gerçeklik ise, hipergerçekliğin tamamlandığı son noktadır ve Baudrillard'ın düşüncesinde teknolojinin yerini en net gösteren ifadelere sahiptir. Baudrillard için sanal gerçeklik, insanların yüz yüze gelmediği, tüm dünyayı sarmalayan ve dünyanın televizyon ve internet gibi yazılı ve görsel iletişim araçları aracılığıyla algılanarak çözümlenmesi ve bu çerçevede yorumlanması sonucunda ortaya çıkan yeni bir gerçekliktir (Baudrillard, 2015:8). Baudrillard sanal gerçekliği ele alırken bilgisayarı analizinin temeline koyar. Örneğin bilgisayar vasıtasıyla bestelenen 'kusursuz' bir müzik, ne kadar kusursuz olursa olsun gerçek müzik olmaktan uzaktır; çünkü düş gücü yerini bilgisayarın sanal gerçekliğine bırakmıştır (Baudrillard, 2015:24).

Michel Foucault ise teknolojiyi modern öznenin kurulumu sürecinde başat güçlerden biri olarak ele alır. Normal olan ile olmayan arasındaki ayrımı karakterize ederken Foucault normal olanın kendisini normal olmayan üzerinden tanımlayarak normalliğini meşrulaştırması üzerinde durur (Foucault, 2012:178). Bu, bir anlamda Foucault'nun modern toplumunu karakterize eden iktidar mefhumunun bir görünüşüdür. Zira Foucault için iktidar yalnızca yukarıdan aşağıya uygulanmaz. İktidar yaşamın her alanında işleyen etkin bir güçtür (Foucault, 2012:177). Teknoloji de iktidarın [ve dolayısıyla modern öznenin] oluşumunda temel bir noktadadır. İktidarın tüm disipline edici ve düzenleyici pratikleri Foucault için teknolojiyle bağlantılıdır. Bu anlamda panoptikon bir iktidar teknolojisidir aslında, zira bedenin bilgisine vakıf olmak bedene egemen olmaktır; bu beden üzerinde ve üzerine inşa edilen siyasal teknolojidir (Foucault, 2015a:63). Disiplinin muktedirin eylemlerinden öznenin kendi eylemlerine kaydığı modern öznenin ortaya çıkışı sürecinin temeli bu anlamda biyoiktidar üzerine kuruludur. Foucault tarihsel biçimde ele aldığı iktidar mefhumunu teknoloji ile bu bağlamda iç içe kullanır ve nihayetinde öznenin kendi kendini disipline ettiği biyo-iktidara ulaşır. Biyoiktidar, özneyi eylemeye iterken bu eylemenin biçimini manipüle eden bir iktidar teknolojisidir (Foucault, 2015b:73-74).

\section{Toplumsal Bir İnşa Olarak Bilim ve Teknoloji}

1970'li yıllarla birlikte bilim ve teknoloji çalışmalarında yeni bir yaklaşımın ortaya çıkışıyla bilim ve teknolojinin sosyolojik yorumu yeni bir boyut kazanmıştır. Söz konusu yaklaşım hem bilimin hem teknolojinin toplumsal inşalar oldukları ön kabulüyle yola çıkan ve bir anlamda hem yapısal hem işlevsel bilim ve teknoloji çalışmalarının tözcülüğüne eleştirel bir bakış açısı sunarak onları yapısöküme uğratan bilim ve teknoloji araștırmaları yaklaşımıdır (Sismondo, 2010:10-11). Bilim ve teknoloji araştırmaları, bilimsel ve teknolojik gerçekliğin sosyal bir inşa olduğu ön kabulüyle hareket eder (Pinch \& Wijker, 1984). Toplumsal olarak inşa edilen "yalnızca insanlar değil, aynı zamanda onların yarattıkları dünyalar, fikirleri ve kullandıkları insanî ürünlerdir" (Bauchspies vd., 2019:22). Bilim ve teknolojinin bir gerçeklik olarak inşasında ise onların doğalarının [toplumsal etkileşimler etrafında inşa edilmeleri bağlamında] toplumsal, [kendi etrafında gerçekliği yeniden üreten bir anlamda] aktif ve [doğayı yorumlayan ve bilgiyi ortaya çıkaran ürünlerinin doğal değil, insan yapımı olması nedeniyle] doğanın kendisinin fikirlere aktarılması kadar basitçe anlaşılamayacak derecede doğal-dışı olduğu söylenebilir (Sismondo, 2010:57). Tüm bunlar etrafında bilimsel gerçekliğin kendini bir gerçeklik olarak sunabilmesi, bir anlamda bir mitin inşa edilmesi sürecini takip etmektedir. Bu mitin inşasında bilimin temel kavramları olan olgu, teori, yöntem, teknik gibi kavramların toplumsal olarak nasıl inşa edildiklerini ele almak bilimin toplumsal inşasını anlamak açısından önemlidir.

Bilim toplumsal bir inşa ise, onun bir ürünü olan teknoloji de toplumsal bir inşa olarak ele alınmalıdır. Ancak bilim ve teknoloji arasındaki ilişkiyi yalnızca bilimin teknolojiyi belirlediği bir biçimde, tek yönlü ele almak teknoloji ve bilimin toplumsal inşaları sürecinde bir hususu gözden kaçırmamıza neden olabilir: bilim ve teknoloji arasındaki karşılıklı ilişkiyi. Şayet bilim bir mite benzer biçimde inşa ediliyorsa, bu inşadan pay alan -ve bu inşada payı olan- teknoloji hususu ele alınmalıdır. Bu düşünme biçimi bizi sosyo-teknik bir sistem olarak toplum ve teknobilim tartışmalarına götürmektedir. Teknobilim, bilimsel gerçekler ve teknoloji olarak inşa edilen her şeyin üretiminin arka planında olup bitenler olarak düşünülebilir (Sismondo, 2010:81). Bilim ve teknoloji olarak gördüğümüz şeyler, tüm sürecin sonunda bu üretim sürecinin kirli yanlarını geride bırakarak belirli bir azınlık tarafından 
damıtılmış, bir süzgeçten geçirilmiş olan şeylerdir. Yani teknobilim, aslında bilimin ve teknolojinin üretildiği süreçte yaşanan tüm çatışmaları, ittifakları, çıkarlar doğrultusundaki tüm eylemleri, bir anlamda tüm etkileşimleri kapsayan süreci işaret etmektedir. Saf ve yansız bilim olarak algıladığımız şeyler esasında tüm toplumsal kökenlerinden soyutlanmış biçimiyle teknobilimden geriye kalanlardır (Bauchspies vd., 2019:31).

\section{Sosyo-Teknik Sistem olarak Toplum: Bruno Latour ve Aktör Ağ Teorisi}

Bruno Latour ile birlikte anılan aktör ağ teorisi, teknoloji ve bilimin toplum ile olan ilişsisini kavranabilir kılmak amacıyla, kendisinden önce girilmemiş bir yola girer. Kendinden önceki düşünürlerin aksine Latour için bilim, teknoloji ve toplum birbirleriyle ilişkili, özerk alanlar değillerdir; onlar birbirleriyle iç içedirler. Latour'un ve aktör ağ teorisinin bilim, teknoloji ve toplum üçgenindeki ilişkiyi kavrayış biçimini anlayabilmek için öncelikle onun ontolojik yönelimi, dolayısıyla aktör ağ teorisinin ontolojik dayanağı ortaya konulmalıdır.

Latour tözlere karşıdır ve tözcü bir düşünme bizi modernitenin üzerine kurulduğu ikilikler üzerinde hareket etmeye mecbur bırakarak doğa ile toplum, özne ile nesne arasındaki ayrımların gerçekmişçesine algılanmasına hizmet eder. Oysa dünyayı meydana getiren her şey, her aktör ve her eyleyen‡ yalnızca ilişkilerinden ibarettir (Harman, 2009:17-18). Latour, Biz Hiç Modern Olmadık adlı çalışmasında klasik ve çağdaş sosyolojinin "toplum nedir?" sorusuna yanıt ararken temel aldığı ontolojik yaklaşımın (özne yönelimli ontoloji) modernitenin yarattı̆̆ bir yanılsama olduğunu savunur. Ona göre modernite asimetrik bir şey olarak kendini sunar (Latour, 2020:18). Doğa ile toplum, nesne ile özne arasındaki ayrımlara dayanan bu asimetri, modern insanı, toplumun yalnızca insanın insan ile olan ilişkisi bağlamında ortaya çıkan bir şeymişçesine algılanarak, doğa ve toplumun birbirlerinden ayrı iki alan biçiminde düşünülmesine götürür. Bu ontolojik temelde doğa, laboratuvarda insan tarafından yeniden üretilerek topluma içkin bir hâl alır. Oysa doğa ile toplum birbirlerinden ayrı değildirler. Doğal dünyayı meydana getiren her şey, toplumu da meydana getirmektedir. Çok basitçe ifade etmek gerekirse, tüm dünya insan olan ve insan olmayan aktörlerden (eyleyenlerden) meydana gelir ve dünyayı meydana getiren her șey ontolojik olarak aynı zemindedir, dünyada olan her şey yalnızca bir kez olur ve biter. İnsan olsun ya da olmasın, hiçbir aktör, hiçbir eyleyen bir diğerine veya herhangi bir şeye indirgenemez (Latour, 2010:158).

Latour, tüm toplumsallığın aktörlerden ve eyleyenlerden oluşan ağların içersinde gerçekleștiğini savunur. Doğa ile toplum birbirlerinden ayrı değillerdir ve farklı dilleri konuşmazlar. Farklı dilleri konuşan, onların bilgilerini birbirlerine aktaran aktör ve eyleyenlerdir. Bir anlamda söz konusu olan bir iletim sürecidir. Latour bu sürece "tercüme" adını verir. Bu süreçte doğal olan her şey, toplumsal olana tercüme edilir (Latour, 2020:19). Bu tercüme süreci, şeyleri birbirine bağlamanın anahtarıdır. Doğal olanın toplumsal olana tercümesi, doğanın saf bilgisini ortaya çıkarmak değil, onun yorumlanması sürecidir. Bu sürece dahil olan ve bu bağlantıyı sağlayan her şey, insan olsun ya da olmasın, bu sürecin bir aktörü hâlini alır ve gerçekliği kendince manipüle ederek tercüme sürecine katılır (Harman, 2009:14-15). Şüphesiz ki bu tercüme sürecinin en önemli iki aktörü, doğanın bilgisini yorumlayarak toplumsal olana tercüme eden bilim ve onun ayrılmaz bir parçası olan teknolojidir. Bir anlamda Latourcu bir düşünme biçimi görülen her şeyde bu iki fenomenin izlerini aramaktır da diyebiliriz.

Latour'un sorduğu "Pasteur'den önce mikroplar neredeydi?" sorusu (Latour, 2000:145) teknoloji ve bilimin toplumdaki mahiyetine dair çok önemli bazı noktalara değinmektedir. Soru her ne kadar klasik görünse de, Latour'un bu soruya verdiği yanıt, son derece yenilikçi ve kimi zaman radikaldir. Pasteur onların varlığını kanıtlayana kadar şarbon mikrobunun varlığını iddia edebilir miyiz? Latour'un bu soruya yanıtı hayırdır, Pasteur'den önce mikroplar yoktur (Latour, 2010:89). Elbette bu yanıt retorik bir yanıttır ve Latour'un aktör ağ teorisini dayandırdığı ontolojik probleme, yani dünyayı yapan özne olarak insan yaklaşımının açmazına işaret etmektir. Söz konusu problemi ve yarattığı açmazı Latour şu şekilde formüle eder: Pasteur'den önce mikroplar yoktur, çünkü varlıkları bilinmemekte, dünyaya olan dokunuşları anlamlandırılamamaktadır. Pasteur yaptığı çalışmalarla bu mikrobu icat etmiş olur; dolayısıyla mikrop bir nesne olarak, özne olan Pasteur'ün eyleminin bir sonucudur. Özne ile nesne arasındaki bu ikilik Pasteur ve mikropların birbirlerinden önceki tarihi

\footnotetext{
\# Kavramın tam karşılığı actant olup, kelimenin -to act, yani eylemek/eylemde bulunmak kökünden gelen yapısı ve Latour'un düşüncesi etrafında düşünüldügüunde Türkçe karşılık olarak eyleyenin kullanılabileceğini düşünüyoruz.
} 
ortak paylaşımlarının önünde bir engeldir (Latour, 2000:149). Bu durumun yarattığı paradoks bir anlamda modernliğin paradoksudur, Latour bu paradokstan çıkışı aktör ağ teorisinde bulur.

Bilim de tüm toplumsal alanlar ve toplumun kendisi gibi yalnızca insan aktörlerden menkul değildir. Laboratuvarlar ve içerisindeki her şey, canlı ya da cansız olsun, akıl sahibi olsun ya da olmasın, pratik eylemde bir paya sahiptir (Latour, 2020:34). Aktör ağ teorisinin alametifarikası da burada ortaya çıkar. Latour aktör ve eyleyen§ arasındaki bağı kurarak teknoloji ve bilimin birbirleri ile olan ilişkisel durumlarına dikkat çeker. Bu bağlamda bir aktör olan insanın eylemini düzenleme kapasitesi olan insan-olmayan şeylerin bu eylemdeki payı yadsınamaz. Onlar yalnızca nesne olarak ele alınamazlar. Zira kendilerine özgü öngereklilikler ile donanmışlardır. Herhangi bir eylem için değil, belirli bir eylem ve belirli bir yöntem için vardırlar ve eylemin yapısını belirlemekte etkin rol oynarlar. Bu şeyleri özne olarak tanımlamak da mümkün değildir. Zira en basit tabiriyle kendi akılları yoktur ve eyleme kabiliyetleri de birinin müdahalesiyle paraleldir. İște bu şeyler, aktör ağ teorisinde insan aktörlerin eylemlerini düzenleyici bir güç sahibi olan, aktörün algısını manipüle ederek gerçekliği değiştirmeye muktedir eyleyenlerdir (Latour, 2004:75).

Latour eyleyenler arasında ikili bir ayrım yapar. Birinci tip olarak ele alınabilecek olan aracı eyleyenler* anlamı veya kuvveti yalnızca iletirken, dönüştürmek gibi bir durumları yoktur. Onlar stabil ve tahmin edilebilir çıktılara yönelik eylemde bulunurlar. Dolayımcı eyleyenler* ise tam tersine stabil değillerdir ve çıktıları tahmin edilemez. Onlar taşımakta ve iletmekte oldukları anlamlar ile bileșenleri bozuma uğratabilecek, dönüștürebilecek ve farklı biçimlerde üretebilecek bir yapıdadırlar. Bir bilgisayar dolayımcı eyleyen için iyi bir örnektir; kullanmayı bilmemesi durumunda, bilgisayar (eyleyen) kullanıcının (aktör) eylemini saptırabilir (Latour, 2005:39). Bu ilişkisellik, ağların ve ağlardan oluşan toplumun ilișkiselliğidir. Yukarıda da bahsettiğimiz üzere, bir eyleyen, aktörün eylemini manipüle ederken bunu belirli bir niyetle yapmaz, zira o canlı olmayabilir, canlı olsa dahi akıl sahibi bir varlık olmayabilir. Ancak, yukarıda bahsettiğimiz üzere doğanın topluma ve toplumun doğaya tercümesinde, birbirleriyle ayrı gibi görünen, ancak aslında bir bütün olan bu iki alanın bilgisi bu eyleyenlerin yorumundan geçerek aktöre, yani insana ulaşır. Bu, Latour'un simetrik bilim ontolojisinin temel argümanıdır (Latour, 2005: 109).

$\mathrm{Bu}$ durumda Pasteur'ün aktör ağ teorisindeki yerini bir aktör olarak saptayabiliriz. Mikroskop Pasteur için bir müttefik hâlini alırken aktif bir roldedir, çünkü onun algısını yapılandırmaya muktedirdir. Pasteur'den önce de şarbon mikrobu elbet vardl, ancak mikroskop (eyleyen) ve Pasteur'ün (aktör) ilişkiselliği şarbon mikrobunu algılanabilir kılmıştır (Latour, 2010). Ayrıca Pasteur'ün bilimsel ilgi ve çıkarlarından ötürü bu mikropları tanımlama ve kategorize etme biçimleri de onun bir aktör olarak ağını genişleterek yeni ittifaklar kurmasına da neden olmuştur; Pasteur'ün bilimsel ilgisinin şarbon mikrobuna yönelik bir aşı bulmaya yönelik olması onun ağını biyokimyacılar ve sınıflandırmacılar gibi teorik bilimcilerdense doktorlar, veterinerler ve biyologlar gibi gruplara doğru genişlemesine neden olmuştur (de Vries, 2016:59-60). Nihayetinde, aktör ağ teorisi bağlamında bilim, yalnızca [özne olan] insanın değildir. Bilim (ve diğer tüm toplumsal alanlar) insan ve insan-olmayanların ortak yaratımları olan ağlardır. Her şey ağların içerisinde gerçekleşir, Latour'un deyişiyle ağlar “yeri ve göğü birbirine katarlar" (Latour, 2020:19).

\section{Sonuç}

Teknoloji yalnızca en yakından ilişkili göründüğü bilim alanı ve iktisadi alan gibi alanlarla değil, toplumsallığın tüm alanlarına etki etmekte ve o alanlar tarafından etkilenmektedir. Bir başka deyişle, teknoloji toplumsallığın ayrılmaz bir parçasıdır. Modern sanayinin ortaya çıkışıyla birlikte teknoloji başta meslekler ve işin yapısında önemli değişmeler ortaya çıkarmıştır. İnsanın kas gücüyle yaptığı işi değiştirip, kasın yerine makinenin gücünü koyan teknoloji hem toplumsal ilerlemeyi hızlandırmış, aynı zamanda kitlesel işsizlik, vasıfsızlaștırma gibi önemli toplumsal sorunları da etkileyen bir fenomendir. Dolayısıyla sosyolojinin teknoloji üzerine ilgisi de klasik sosyologların metinlerinden

\footnotetext{
* Bu kavram da yine Latour'un terminolojisinde intermediary actant olarak kullanılmaktadır. Latour'un bahsettiği şekliyle, bilgiyi yalnızca iletme işlevi üzerinden hareket ettiğimizde, bu kavramı aracı eyleyen olarak Türkçeleştirmeyi uygun buluyoruz.

* Latour'un terminolojisinde bu kavram mediatory actant olarak kullanılmaktadır. İlișkileri ve anlamı manipüle etme kapasitesi üzerinden aracı eyleyenle ayrılan bu eyleyen biçimi, kendi dolayımında yeni ilişkileri ortaya çıkarabilmeye muktedir olduğundan dolayımcı eyleyen olarak Türkçeleştirmeyi uygun buluyoruz.
} 
itibaren gözle görülür bir hâldedir. Günümüz dünyasında ise teknoloji yalnızca bilimsel ve iktisadi alanlarla değil, gözetim ve kontrolden sağlık alanına, gündelik hayata kadar birçok toplumsal alanda başat belirleyici toplumsal güçlerden biri hâlini almıştır. Otomasyon süreçlerinin ișe etkisi ile iktisadi alanda büyük dönüşümlerin temel güçlerinden biri olan teknoloji, akıllı sistemler ve yapay zekâ ile sağlık alanında, güvenlik, gözetim ve kontrol alanlarında insan faktörünün etkisini sınırlamaya başlamıştır. Bu bağlamda sosyolojinin teknolojiye olan ilgisi sürmekle beraber, bu değişim ve dönüşümlerin ekseninde yeni yaklaşımlar ve çalışma alanlarıyla beslenmektedir.

Klasik sosyolojiden, hatta sosyolojinin kuruluşundan önce dahi teknolojiye kimi zaman örtük, kimi zaman açıktan bir ilgi olduğu barizdir. Klasik yaklaşımlardan çağdaş yaklaşımlara kadar, tüm toplum kavramsallaştırmalarında teknolojinin etkileri modern sosyolojide belirgin olduğu belirtilmelidir. Ancak, gerek klasik kuramlarda gerek çağdaş kuramlarda, her ne kadar benzer tarihsel süreçleri farklı biçimlerde açıklamaları nedeniyle sıklıkla birbirlerine rakip olarak konumlandırılan geç modernite ve postmodernite yaklaşımlarının en temel benzerlikleri teknolojiyi kavrayış biçimlerinde olduğu söylenebilir. Tarihsel olarak sosyoloji içinde teknoloji çözümlemeleri, yaklaşımları ve odağa aldıklarını değiştirseler de, tümünü bağlayan ontolojik bir yönelim vardır. Marksist sosyolojiden, Bilim ve Teknoloji Araştırmaları'na kadar tüm bu yaklaşımlar özne yönelimli bir ontoloji üzerinde temellenirler; toplumsallık, insanın insan ile olan ilişkisidir ve toplum olarak adlandırdığımız şey, insanlar arasındaki ilișkiler üzerinde inșa edilir. Marksist sosyolojinin tahakküm ilișkilerinin bir aracı olarak teknoloji çözümlemesi, fenomenolojik yaklaşımda teknolojinin insan eylemine olan etkisi, geç modernite ve postmodernite tartışmalarında teknolojinin bir felaketin sebebi, bir gözetim ve disiplin aracı, bilginin mahiyetini ve dolayısıyla toplumsal ilişkileri değiștiren bir fenomen olarak ele alınması, Bilim ve Teknoloji Araştırmalarının aktif, ancak toplumsal olarak inşa edilmiş bir fenomen olarak teknoloji çözümlemesi gibi yaklaşımların her biri teknolojiyi insan eyleminin bir sonucu olarak ele alan özne yönelimli bir ontoloji üzerinde temellenir.

Bruno Latour ise teknolojinin sosyolojik çözümlemesinde sosyolojinin daha önce girmediği bir yola girerek öncelikle ontolojik bağlamda bir değişmeye ihtiyaç olduğuna dikkat çeker. Ona göre toplumsal eylem yalnızca insanın eylemi olamaz, insanı bu eylemi eyleyebilir kılan tüm varlıklar toplumsal eyleme aktif olarak katılırlar. Dolayısıyla teknoloji insan eyleminin bir ürünü olduğu kadar, insanın eyleme kapasitesini de doğrudan etkileyen, onu değiştiren ve dönüştüren bir şeydir. Latour bu ontolojik kabulün üzerine aktör ağ teorisini inşa etmiştir. Bu teoriye göre toplum olarak adlandırdığımız şey iç içe geçmiş ağlardan oluşan bir sistemden başka bir şey değildir. Bu sistemler bütünü içerisinde, her ağda gerçekleşen her eylem o ağda bulunan herkesin ve her şeyin ortak ürünüdür. Şarbon mikrobunun keşfinde Pasteur kadar mikroskobun da payı vardır, bir metro ağı yalnızca insanları bir noktadan diğerine götürmekle kalmaz, onlara hangi güzergâhı izleyeceklerini, hangi noktalarda duracaklarını da söyler; her ağ kendi içindeki sonsuza uzanan sayıdaki ağdan meydana gelir ve tüm toplumsal eylem bu ağlar içerisinde gerçekleşir.

Latour'un girdiği bu cüretkâr yol bize teknolojinin toplumsallığın üretiminde ve istikrar kazanmasında insan ile birlikte başat bir konumda olduğunu söylemektedir. Bu iddia son derece cüretkâr olduğu kadar zihin açıcıdır da. Homo faberden beri alet ile kurduğu ilişkinin neticesinde dünyayı değiştirip dönüştürme kabiliyetine ulaşan insan, toplumsallaşırken teknolojinin uzağında hiç kalmamıştır. Buharlı makinelerden dizüstü bilgisayarlara, kömürle çalışan trenlerden ses hızını aşan uçaklara kadar değişen bir görüntüde, insanın kendine atfettiği her anda teknolojinin de yanında olduğu ortadadır. Tüm bunların yanında, günümüzün en çok tartışılan, hayatımızı en çok belirleyen ve yakın geleceğimizde çok büyük bir damga vurması beklenen yapay zekâ gibi bir teknolojik fenomeni, sosyolojinin yalnızca insanın bir ürünü, insanın insan ile ilişkisinde kullandığı bir araç olarak ele alarak açıklayabileceği düşüncesi her geçen gün ve gelişmeyle geçerliliği sorgulanır hale gelmektedir. Bu durumdan ve hem öznelci hem nesnelci indirgemelerden kaçınmak adına, sosyolojinin teknolojiyi toplumsallı̆̆ın merkezinde bir aktör olarak ele alması gerektiği söylenebilir. Bunun için başlangıca dönmek, bilgi ve yöntemden önce şeylerin mahiyetini düşünmek gerekmektedir. Tarihsel birikimini kaybetmemiş bir teknoloji sosyolojisi, Marksist sosyolojiden Latourcu sosyolojiye kadar birçok alandan beslenerek, demokratik bir ontoloji üzerinde temellendirilebilir. 
Hakem Değerlendirmesi: Dış bağımsız.

Çıkar Çatışması: Yazarlar çıkar çatışması bildirmemiştir.

Finansal Destek: Yazarlar bu çalışma için finansal destek almadığını beyan etmiştir.

Peer-review: Externally peer-reviewed.

Conflict of Interest: The authors declare no potential conflicts of interest with respect to the research, authorship, and/or publication of this article.

Grant Support: The authors received no financial support for the research, authorship, and/or publication of this article.

\section{Kaynakça/ References}

Adas, M. (1990). Machines as the measure of men: Science, technology and ideologies of western dominance. NY: Cornell University Press.

Adorno, T. W. (2014). Kültür endüstrisi: Kültür yönetimi. (N. Ülner, M. Tüzel, E. Gen, Çev.). İstanbul: İletişim Yayınları.

Bauchspies, W. K., Croissant, J., ve Restivo, S. (2019). Bilim, teknoloji ve toplum: Sosyolojik bir yaklaşım (B. Kuryel, Ü. Tatlıcan ve B. Balkız, Çev.). Ankara: Phoenix Yayınevi.

Baudrillard, J. (2015). Şeytana satılan ruh: Ya da kötülüğün egemenliği (0. Adanır, Çev.). Ankara: Doğu Batı Yayınları.

Baudrillard, J. (2016). Simülakrlar ve simülasyon (O. Adanır, Çev.). Ankara: Doğu Batı Yayınları.

Beck, U. (1998). The politics of risk society. J. Franklin (Ed.) The politics of risk society içinde (ss.922). Cambridge: Polity Press.

Beck, U. (2011). Risk toplumu: Başka bir modernliğe doğru (K. Özdoğan, B. Doğan, Çev.), İstanbul: İthaki Yayınlarl.

Beniger, J. (1986). The control revolution: Technological and economic origins of the information society. Massachusetts: Harvard University Press.

Braverman, H. (1998). Labor and monopoly capital: The degradation of work in tweintieth century. New York: Monthly Review Press.

Castells, M. (2009). The rise of the network society. New Jersey: Wiley-Blackwell Publishing.

Collin, F. ve Pedersen, D. B. (2015). The Frankfurt school, science and technology studies, and the humanities. Social epistemology 29(1), 44-72.

Comte, A. (2009a). The positive philosophy of Auguste Comte. New York: Cambridge University Press.

Comte, A. (2009b). The cathecism of positive religion. New York: Cambridge University Press.

de Vries, G. (2016). Bruno Latour. Cambridge: Polity Press.

Durkheim, E. (1994). The division of labour in society. London: Macmillan.

Feenberg, A. (2017). Critical theory of technology and STS. Thesis eleven, 138(1). 3-12.

Feenberg, A. (2010). Eleştirel teknoloji teorisi: Genel bir bakıș. G. Ruivenkamp, J. Jongerden, M. Öztürk (Ed.), Teknoloji ve toplum: Yıkıcı bir direniş ve yeniden yapılanma (C. Atay, Çev.). İstanbul: Kalkedon Yayınları.

Foucault, M. (2012). İktidarın gözü: Seçme yazılar 4 (I. Ergüden, Çev.). İstanbul: Ayrıntı Yayınları.

Foucault, M. (2015a). Hapishanenin doğuşu (M.A. Kılıçbay, Çev.). Ankara: İmge Kitabevi.

Foucault, M. (2015b). Büyük kapatılma: Seçme yazılar 3 (I. Ergüden, F. Keskin, Çev.). İstanbul: Ayrıntı yayınları.

Giddens, A. (1991). The consequences of modernity. California: Stanford University Press. 
Giddens, A. (2010). Modernite ve bireysel-kimlik: Geç modern çağda benlik ve toplum (Ü. Tatlıcan, Çev.). İstanbul: Say Yayınları.

Gorz, A. (1987). Farewell to the working class: An essay on post-industrial socialism. London: Pluto Press.

Habermas, J. (1981). New social movements. Telos, (49). 33-37.

Harman, G. (2009). Prince of networks: Bruno Latour and metaphysics. Melbourne: Re.press.

Harvey, D. (2005). A brief history of neoliberalism. New York: Oxford University Press.

Heidegger, M. (1977). The question concerning technology and other essays. New York: Garland Publishing.

Heise, U. K. (2004). Science, technology and postmodernism. S. Connor (Ed.), The cambridge companion to postmodernism içinde (136-167 ss.). New York: Cambridge University Press.

Ihde, D. (1979). Techincs and praxis. Boston: D. Reidel Publishing.

Ihde, D. (1990). Technology and the lifeworld. Indiana: Indiana University Press.

Ihde, D. (2010). Heidegger on technology: One size fits all. Philosophy Today (54). 101-105.

Latour, B. (1996). Aramis or the love of technology. Massachusetts: Harvard University Press.

Latour, B. (2000). Pandora's hope: Essays on the reality of science studies. Massachusetts: Harvard University Press.

Latour, B. (2003). Science in action: How to follow scientists and engineers through society. Massachusetts: Harvard University Press.

Latour, B. (2004). Politics of nature: How to bring the sciences into democracy. Massachusetts: Harvard University Press.

Latour, B. (2005). Reassembling the social: An introduction to actor-network theory. New York: Oxford University Press.

Latour, B. (2010). The pasteurization of france. Massachusetts: Harvard University Press.

Latour, B. (2020). Biz hiç modern olmadık. (İ. Uysal, Çev.). İstanbul: Norgunk Yayıncılık.

Lyotard, J. F. (1984). The postmodern condition: A report on knowledge. Minneapolis: University of Minnesota Press.

Marcuse, H. (1998). Some social implications of modern technology. A. Arato, ve E. Gebhart (Ed.), The essential Frankfurt school reader içinde (138-162 ss.). New York: Continuum Publishing.

Marcuse, H. (2007). One-dimensional man: Studies in the ideology of advanced industrial society. New York: Routledge.

Marx, K. (2005). Toplumbilimsel yazılar: Seçme metinler. (Ö. Ozankaya, Çev.). İstanbul: Cem Yayınevi.

Marx, K. (2016). Makina üzerine fragmanlar (B. Denizci, Çev.). İstanbul: SUB Yayınları.

Marx, K. (2018). 1844 el yazmaları (M. Belge, Çev.). İstanbul: İletişim Yayınları.

Marx, K. (2019): Kapital: Ekonomi politiğin eleştirisi, I. cilt. (M. Selik, N. Satlıgan, Çev.). İstanbul: Yordam Kitap.

Melucci, A. (1980). The new social movements: A theoretical approach. Social Science Information, 19(2). 199-226.

Mertel, K. C. M. (2020). Heidegger, technology and education. Journal of Philosophy of Education, 54(2). 467-486.

Mishra, R. (1979). Technology and social structure in Marx's theory: An exploratory analysis. Science \& Society, 43(2), 132-157. 
Müller, H. (1994). Social differentiation and organic solidarity: The "division of labor" revisited. Sociological Forum, 9(1), 73-86.

Noble, D.F. (2011). Forces of production: A social history of industrial automation. New Jersey: Transaction Publishers.

Pinch, T. J. \& Bijker E. B. (1984). The social construction of facts and artefacts: Or how the sociology of science and the sociology of technology might benefit each other. Social Studies of Science, 14(3). 399-441.

Pope, W.P. \& Johnson, B. D. (1983). Inside organic solidarity. American Sociological Review, 48(5), 681-692.

Saint Simon, H. (1964). Social organization, the science of man, and other writings. New York: Harper \& Row.

Saint Simon, H. (1975). Henri de Saint Simon, 1760-1825: Selected writings on science, industry and social organization. New York: Holmes and Meier Publishers.

Scharff, C. (2012). Don Ihde: Heidegger's technologies: Postphenomenological perspectives. Continental Philosophy Review, (45). 297-306.

Sismondo, S. (2010). An introduction to science and technology studies. Sussex: Blackwell Publishing. Standing, G. (2011). The precariat: The new dangerous class. New York: Bloomsbury.

Touraine, A. (1985). An introduction to the study of social movements. Social Research, 52(4). 749787.

Turanl, A. (2017). Martin Heidegger on technology: A response to essentialist charge. Kilikya Felsefe Dergisi (2). 1-16.

Weber, M. (1958). The protestant ethic and the spirit of capitalism. New York: Scribner.

Weber, M. (1975). Science as a vocation. H. Gerth, C. W. Mills (Ed.), From Max Weber: Essays in sociology içinde (ss. 129-159). New York: Oxford University Press.

Weber, M. (1978). Economy and society: An outline of interpretive sociology. California: University of California Press.

Webster, F. (2006). Theories of the information society. New York: Routledge.

Wendling, A. E. (2009). Karl Marx on technology and alienation. New York: Palgrave Macmillan. 